\title{
Can we reconcile? Understanding the multi-level challenges of conflict
}

\section{transformation}

\author{
Sarah Maddison \\ School of Social and Political Sciences \\ University of Melbourne \\ sarah.maddison@unimelb.edu.au
}

\begin{abstract}
Reconciliation and conflict transformation require simultaneous effort across several socio political levels. This article advances both a conceptual and an empirical argument to frame reconciliation and conflict transformation in these terms. First, the article draws on theories of agonistic democracy to argue for the intrinsic and potentially productive role of non-violent conflict in reconciliation efforts that accept conflict as both enduring and necessary. Second, the article contends that reconciliation is a multi-level task that requires ongoing attention and effort directed towards constitution building, institutional reform, and relational transformation. The paper concludes that, once conflict transformation is understood in these terms, reconciliation must be seen as a far more difficult and long-term endeavour than is usually acknowledged, requiring innovative political institutions capable of keeping open spaces for democratic political contestation.
\end{abstract}

\section{Key words}

Reconciliation, conflict transformation, agonism, constitutional, institutional, relational

Sarah Maddison is Associate Professor of Politics in the School of Social and Political Sciences at the University of Melbourne

\section{Statement on funding sources}

This work was supported by an Australian Research Council Future Fellowship, grant number FT100100253 


\section{Can we reconcile? Understanding the multi-level challenges of conflict transformation}

\section{Introduction}

This article is concerned with the challenges and (im)possibilities of reconciliation. Framed around the question, 'Can we reconcile?', in what follows I consider the complex, ongoing political challenges involved in attempting to restore broken relationships and find ways to live together, democratically and non-violently, with radical differences (Ramsbotham, Woodhouse, and Miall, 2011: 246). I contend that negotiating these multi-level challenges is essential to a vibrant democratic politics, underscoring the need for political institutions capable of engaging deeply divided societies in modes of agonistic contestation.

This article is informed by the work of theorists such as Andrew Schaap (2005) and Adrian Little (2014), inter alia, whose application of theories of agonistic democracy to the field of reconciliation has helped advance scholarship in this area. Agonistic theorists make a normative claim for the need to keep open political spaces in which conflict can be engaged, suggesting the need to rethink the intrinsic and potentially productive role of non-violent conflict in advancing democracy and political reconciliation in deeply divided societies. In an important departure from these approaches, however, I apply these theoretical propositions across the multiple sociopolitical levels at which I contend that transformation is required. I argue that, understood in these terms, conflict transformation is more complex and open-ended than is generally acknowledged in the reconciliation literature. This argument is intended to counter some of the impatience that imbues much discussion of 
reconciliation and conflict transformation, and the suggestion that people - and countries - need to put both the politics and the traumas of the past behind them and 'move on' from their conflicts (Christodoulidis and Veitch, 2007: 1; Hirsch, 2012: 3). Counter to this, I argue that simplicity and impatience in reconciliation politics is not only unrealistic, it is, as the literature on agonism suggests, inherently dangerous, as it drives enduring social and political conflict underground from where it will inevitably surface in unpredictable and violent ways.

Developed first in relation to 'transitional' societies emerging from periods of authoritarian rule or civil war, the politics of reconciliation has, in recent decades, expanded to include the efforts of 'established' or 'consolidated' democracies, notably settler colonial societies still grappling with historical wrongs, such as Australia and Canada (Bashir and Kymlicka, 2008: 3-4). Over time the term has come into increasing political usage, and scholars of political science have engaged with reconciliation in both theory and empirical study. Despite these efforts, however, there remains a significant lack of agreement about the meaning, content, staging, timing, and ability to measure reconciliation efforts by a range of political actors, including governments, civil society organisations, and donors (Daly and Sarkin, 2007: xiii). High profile processes such as the South African Truth and Reconciliation Commission (TRC) have tended to narrow and dominate the field (Renner, 2012: 51), with such events receiving a high level of investigation relative to other conflict transformation efforts.

Much research has attempted to define the concept of reconciliation in an effort to 'boil it down' to an agreed policy framework (Renner, 2012: 55). As Erin Daly and Jeremy Sarkin suggest (2007: 4), however, the immediate appeal and widespread 
promotion of reconciliation has led to the neglect of key questions, with scant attention being paid to either the specifics or complexities of the paradigm. Further, as some of the promise of post-conflict efforts in South Africa and elsewhere has faded in light of ongoing challenges, a more critical perspective on the meaning and possibility of reconciliation has emerged (Little, 2014: 92). These debates continue, offering divergent and contradictory understandings of the concept. The following section draws on one strand of political theorising about reconciliation to develop a framing of the concept that draws on agonistic democracy theory.

\section{Conflictual reconciliation}

Much reconciliation literature continues to focus on the normative ambition of achieving an idealised social harmony in the mode of South Africa's ideal of a peaceful 'rainbow nation' (see Tutu, 1999), centred on the kinds of 'maximalist' models of reconciliation discussed in the introduction to this special issue. In contrast, a fully political understanding of reconciliation recognises the futility of attempting to transcend conflict in this way, instead framing reconciliation as 'a potentially agonistic clash of worldviews within the context of a community that is "not yet" (Schaap, 2005: 4). In Schaap's view, a 'politically adequate conception of reconciliation' would be alive to the inherent risk of politics, that is, 'that community is not inevitable and that conflict may turn out to be irreconcilable':

...if the ideal of reconciliation is to open up a space for politics between former enemies rather than cover over the conflicts that threaten their political association, reconciliation should be kept in view for being a potentiality of action in the present, which depends upon accepting the 
risk of politics (and the opportunity it presents) rather than eliding it (Schaap, 2005: 21-2).

This is a profoundly pragmatic approach to conflict, which contests a normative aspiration to 'peace', instead advancing a framework that recognises a 'disorderly mixture of peace and conflict' in which democratic politics and other forms of political expression, including contentious politics, are able to co-exist (Little, 2014: 138). Further, such an approach foregrounds the fact that in assuming that conflict is reconcilable, in the sense of achieving harmony and consensus, the politics of reconciliation become obscured (Schaap, 2004: 524). An agonistic approach, by contrast, holds out the hope that, in spaces of irresolvable conflict, divided societies will expand their political capacities, embrace conflict without violence, and find new ways of respecting old adversaries.

This approach to conflict is not without risks. A more conventional view of violent conflict views it as conforming to a cycle that begins with the development of a latent conflict within society, which later emerges into the public domain. The conflict subsequently escalates before arriving at an often 'hurting stalemate', which in turn leads to de-escalation and the resolution or settlement of the conflict. A period of 'post-conflict' reconciliation is thought to complete the cycle (Brahm, 2003). In reality, however, conflict is a far more complex social phenomenon, which remains embedded in social and political relationships, causing periodic ruptures, contributing to physical and structural violence, and framing and constraining political relationships.

These dynamics have particular force in countries emerging from periods of violence and civil war, or that experience other deep cleavages resulting from historical violence. In these contexts, deep divisions along well-entrenched fault lines retain the 
potential for violence, which in turn rests on histories of ethnic, religious, or linguistic division (Arthur, 2011: 2). And where more stable democracies may be at least partly defined by their capacity to include political conflict between citizens without the eruption of violence, ${ }^{1}$ in deeply divided societies these conflicts tend to produce a heightened sense of anxiety. The threat of violence has a particular potency for citizens who know that security is not something to be taken for granted (Guelke, 2012: 33). Indeed, it is possible that opening up political spaces for conflictual engagement in the wake of violent conflict or civil war may create new channels through which violence can be instigated. Certainly, an approach to reconciliation that recognises the central place of conflict is not without risks.

Yet this concern with risk neglects the fact that conflict is as an essential and everpresent political dynamic that allows opposing groups to engage in passionate democratic contestation. As a political dynamic, conflict derives from, and is inherent to, all social institutions, including in 'economic differentiation, social change, cultural formation, psychological development and political organisation' (Ramsbotham, Woodhouse, and Miall, 2011: 7). Thus, while the desire to end or resolve conflict is understandable, this article instead contends that this is both unrealistic and undesirable. Instead, non-violent conflict is here conceived as a social good, or at least as potentially a social good, but one that requires transformation across multiple socio-political levels if it is to harness its democratic potential rather than devolve into violence. Indeed, this is the central theoretical argument made in this article: while there is certainly risk that political conflict may lead to violence, stalemate, disorder, and other social 'bads,' I am suggesting that the way to avoid such political dead ends is through the engagement of conflict in agonistic terms, rather than through efforts to resolve, repress or otherwise avoid conflict. 
Crucial to advancing this argument is an understanding of agonistic democracy. Agonistic democrats affirm the central place of conflict in any democratic politics, a view that reflects the agonists' concern that anything resembling consensus frequently becomes a means of co-opting and diffusing radical challenges to the status quo (Schaap, 2006: 257). This understanding of political life has particular resonance for societies engaged in a politics of reconciliation, where the need to open - and to keep open-political spaces in which divided and opposing groups can engage is crucial. Indeed, Muldoon and Schaap (2012: 182) contend that reconciliation processes are inevitably agonistic precisely because they open up spaces for contestation between opposing groups that may previously have been closed down by violence and repression. As Ed Wingenbach (2011: 61) has suggested, agonistic engagements provide 'an outlet for passion and dissent' that may in fact make the eruption of violent, antagonistic relations less likely. Thus, rather than bracketing or avoiding conflict, the aim of an agonistic reconciliatory engagement is to 'transform actually or potentially violent conflict into non-violent forms of social struggle and social change' (Ramsbotham 2010: 53).

One well-known formulation of agonism, advanced by Chantal Mouffe (2007; 2005; 2000), asserts that the primary task of democracy is to convert antagonism into agonism and enemies into adversaries. This, as Mouffe suggests, has consequences for how we imagine politics and the nature of the public sphere. Rather than eliminating passions, or attempting to contain them in the private sphere to better support a consensus, these passions can be 'mobilised' towards 'the promotion of democratic designs.' In this way, consensus can be seen as a result of a temporary stabilisation of power - the kind of stabilisation often pursued in divided societies - that inevitably entails some form of exclusion (Mouffe, 2007: 43). In an agonistic mode of 
reconciliation, such stabilisations of power may be acknowledged as sometimes necessary, but always to be resisted. Democracy is envisioned as a 'continual contest among incompatible visions, identities, and projects' in which no view can dominate or assume hegemonic status for very long (Wingenbach, 2011: 21).

Little points to the normative dimension in these formulations of agonism, suggesting that theorists such as Mouffe attempt to 'domesticate' political conflict by 'broadening the spectrum of acceptability in the analytical framing of particular issues' (Little, 2014: 75). In this view, although agonists resist the reconciliatory drive to fabricate social and political consensus, and emphatically do not want to delegitimise disagreement, they do see the potential for politics to more effectively accommodate difference based on the nature of the interaction between conflictual actors. In my view, this normative desire to foreground and yet domesticate conflict is no bad thing. The challenge is to find common ground and some shared ambition while encouraging democratic conflict and dissent from the status quo. What is required is the creation of spaces for agonistic engagement focused on the kinds of reconciliatory transformations needed across all socio-political levels.

\section{Multi-level conflict transformation}

Empirically this article now proceeds to apply this conceptual approach to a framework developed during a four-year research project examining reconciliation in a comparative frame (see also Maddison, 2015). ${ }^{2}$ This original framework considers the demands of reconciliation across three porous, overlapping and interlinked sociopolitical levels: the constitutional, the institutional, and the relational. The multi-level conflict transformation approach suggests that reconciliation and conflict 
transformation are far more complex and open-ended processes than is sometimes acknowledged, involving a diverse cluster of practices that, according to Schaap (2005: 12), include (among others) 'repenting, restoring, punishing, apologising, repairing, forgiving, redeeming, forgetting, remembering, promising and understanding.' To these I would add recognizing and redistributing, along the lines formulated by Nancy Fraser (1997). This approach also drives an understanding of the Janus-faced requirements of political reconciliation, paying attention to social structures as well as psychologies, and encouraging the development of a shared vision that is broad enough to achieve change without demanding either agreement about the past or a singular, shared identity (Daly and Sarkin, 2007: 187). The indepth case study research (which, due to space constraints can only be touched upon in this article) that has informed the multi-level framework outlined below confirms the significance of the multiple spaces in which reconciliatory and transformative efforts must be directed.

\section{Constitutional reconciliation}

Societies emerging from civil war, engaged in a transition from authoritarianism to democracy, or still grappling with colonial and historical dispossession and injustice must all, in their own ways, confront the question of how they are constituted, and in what ways they need to re-constitute themselves. The process of political reconciliation is driven by 'the hope of establishing a new beginning' that is 'selfconsciously enacted in the gap between past and future' (Schaap, 2005: 91). In contrast to a view of reconciliation that sees such a process initiated by public acknowledgment of past wrongs, this view of political reconciliation sees it initiated in the act of constitution itself, in which that public - the 'we' of the society - is in 
fact instantiated. Thus, the work of constitutionalism, in both its political and legal senses, provides a space for politics, which is inevitably a space for conflict and contestation. In the framework outlined here, the constitutional space for political reconciliation involves three elements: settlements and agreements, constitutional design and reform, and citizenship.

Firstly, while the architecture of an agreement or settlement is important, this alone will not predict the success of post-violent conflict transformation. Much research on peace agreements tends to focus only on elite political pacts, although 'like icebergs', these agreements tend to hide much of the conflict that endures beneath the surface (Reilly, 2009: 3). Common among the expectations that weigh on these processes is the idea that an agreement can provide a 'solution' to a conflict, or that an agreement means a conflict has ended (Lederach, 2005: 44). This is rarely the case. Indeed, the ingrained nature of social and political conflict suggests that political agreements in isolation will rarely bring about substantive change (Little, 2014).

Ideally, a newly crafted settlement for a previously divided or violent society will open agonistic spaces in which common ground can be recognised, while protecting from further oppression the identities, cultures, and interests of diverse citizens. Yet, despite these aspirations towards openness, it is common for the drive to 'settle' a conflict, and bring an end to violence and repression, to avoid these agonistic demands, resulting in consensus-based compromises that close down political space with problematic long-term implications. To illustrate this point we can consider the case of South Africa, where many of the compromises reached in the years leading up to the negotiated settlement between the major parties (and the eventual transition to democracy in 1994) were thought crucial to the nation's future stability, and essential 
to avoiding a drawn-out civil war. To move the negotiations forward, the settlement between the African National Congress and the National Party came to rely on what was termed 'sufficient consensus' on the key issues of concern to both parties. And while it is generally regarded that the ANC emerged the 'winner' from these negotiations, in the wake of the changed macro-economic context after 1989 this apparent victory in fact required a concession to the view that radical economic restructuring would risk the 'flight' of white capital and jeopardise the 'delicate balance' on which the settlement process rested (Ramphele, 2008: 24). Indeed, it was argued that South Africa risked complete economic collapse if it pursued the program of radical economic restructuring (intended to provide redress for the gross socioeconomic inequality experienced by the black majority population) outlined in the 1955 ANC Freedom Charter.

The compromise that eventually enabled the settlement was extremely difficult for the ANC, which had long articulated their vision of a National Democratic Revolution (NDR), a concept that 'captured far-reaching social transformation.' Recently the ANC have conceded that opting instead for a 'limited NDR' had the effect of reinforcing existing economic power relations (African National Congress, 2012: 8). Over time, the effect of this change of policy direction, which became known as the 'Great U Turn' (Sparks, 2003), has been to close down spaces for further discussion about the economy, subduing important conflicts in favour of a desired political 'consensus'. And rather than opting to re-open the terms of this settlement in light of considerable social unrest, South Africa seems intent on pursuing the neoliberal economic policies that underpinned the settlement, despite enduring and racialised conflicts between labour and capital that still threaten to undo the very peace it was intended to bring about. 
Developments since 1994 would suggest that 'a second national conversation' that would prioritise material need and social diversity is now as important as the conversations that led to the 1994 agreement (Villa-Vicencio and Soko, 2012: 35). Leon Wessels (2010: 11) contends that South Africa needs to 'agree to dialogue' about what he describes as the 'smouldering issues' of racism, poverty and crime, a dialogue without which many South Africans remain 'strangers to one another.' These proposals support the argument that addressing (re)distribution in South Africa will require a move towards a more agonistic approach and the embrace of a more open ended, conflict-laden engagement.

Beyond settlement, a country attempting to re-constitute itself must develop a new political 'container' in which to govern itself. Often this will take the form of a new or radically revised legal constitution that will allow former enemies to develop ways of governing together, contributing to reconciliation through the creation of legal frameworks and institutions that protect rights and diversity (Daly and Sarkin, 2007: 216, 218). But while Daly and Sarkin (2007: 217) contend that a new government 'needs the strong backing of an emphatic constitution' in order to manage the tensions experienced in deeply divided societies, an agonistic view maintains that a constitution should instead open more contingent political space in which such tensions can be engaged and contested.

The 'we' that is imagined in a constitution is not settled by the creation of a legal founding. Instead, according to Schaap, a legal constitution risks foreclosing future opportunities to contest the terms of the relationship (Schaap, 2007: 28). In contrast, an agonistic view sees a constitution as capable of both enabling democratic contestation and as 'the ongoing product of this activity', meaning that a constitution's 
authority will always depend upon its capacity to sustain rather than constrain democratic activity (Wingenbach, 2011: 55). Constitutions should, in other words, be living documents that derive their authority from the capacity to foster rather than foreclose democratic conflict over their own meanings. Practices such as constitutional conventions may provide a venue in which agonistic democratic contestation over proposed constitutional reforms may occur, but there is still much to understand about the ways in which such processes may unfold. ${ }^{3}$

In practice, constitution making tends to favour stability over openness, with particular implications for reconciliation efforts. The Australian settler state, which has struggled to reform its constitution to reflect its colonial past and the place of Aboriginal and Torres Strait Islander people as First Peoples within the nation, well illustrates this point. Indeed, Australia is currently engaged in a process of constitutional reform that is attempting to provide a very modest form of recognition for Indigenous peoples, that is, to re-open the constitutional conversation about the nation's founding in a very bounded manner. Although Australia's constitutional and legal order is regarded as one of the world's most stable and popularly supported systems, it has long been pointed out that this stability rests on what Melissa Castan (2000: 202-3) describes as some 'inherent defects' that undermine its acceptance by indigenous people. Chief among these is the constitution's neglect of the historical dispossession of Aboriginal and Torres Strait Islander peoples. Castan maintains that until such defects are addressed 'reconciliation of our past history with our present aspirations for justice will remain unattainable.'

In the early part of the current campaign and public debate, however, it has become evident that the proposed reforms will not create the agonistic space that is needed for 
meaningful transformation. The loudest dissenting voices speaking out against the proposed reforms have come from Aboriginal people who insist that recognition within what they see as an illegitimate constitution does not address their fundamental political claims. Indeed, the assertion of indigenous sovereignty 'seeks a fundamentally different relationship' with the Australian state (Behrendt, 2003: 103). The 'we' that many Aboriginal and Torres Strait Islander peoples constitute situates itself outside of the Australian nation-state. Creating space to engage with these political claims would, however, require a far more agonistic engagement with Australian constitutionalism than the current approach, which primarily emphasises continuity and stability.

Finally, at the constitutional level, there is a need to focus on the reconstitution of the category of 'citizen' - who does or does not constitute the nation, who does and who does not belong in the post-violent conflict state. An agonistic view of citizenship insists on relations of 'adversarial respect' between 'interlocking and contending constituencies' rather than pursuit of communitarian ideas of consensus (Connolly, 1991: x). It accepts the right of others to hold different views and values, which should be accepted as an important contribution to the debates that enliven democracy. This type of coexistence may be framed as 'accommodation' or as 'toleration', but it should emphatically avoid any form of assimilation, integration, absorption, or forced unification (Daly and Sarkin, 2007: 205). Rather, the form of tolerance that is required in agonistic reconciliation rests on respect for the other as a moral equal, allowing members of a community to see themselves as part of a shared community even though they continue to strongly disagree. 
Political reconciliation has a central concern with the ways in which opposing groups in divided societies learn to live together and reckon with their own widespread participation in violence, as both victims and perpetrators who now must live and work with one another (Daly and Sarkin, 2007: 9). For reconciliation to be political, citizens must hold a commitment to sharing a polity with their historical enemies or oppressors, not transcending former enmity but transforming it into a relation of civic friendship (Schaap, 2007: 15). Indeed, Verdeja defines reconciliation as 'a condition of mutual respect among former enemies, which requires the reciprocal recognition of the moral worth and dignity of others' such that citizens are able to acquire new, postviolence identities that 'cut across those earlier fault lines' (Verdeja, 2009: 3).

However, political reconciliation does not presuppose a prior community that requires restoration, but instead recognises the possibilities that may be revealed in political interactions between contested identity categories (Schaap, 2005: 84). The challenge for reconciliation is to create a nation and a national identity able to contain all groups and the contests among and between them, 'not by forcing parties to move closer together but by providing a new conception of the state to which all parties are committed' (Daly and Sarkin, 2007: 188). This concern is of particular relevance in historically divided societies like Australia, in which one or more group has experienced historical exclusion and marginalisation, as discussed above. In these cases, what is required is the transformation of a range of social institutions.

\section{Institutional reconciliation}

The institutional level of the multi-level framework for reconciliation recognises that overcoming structural injustice will open spaces in which further transformation can 
occur (Ramsbotham, Woodhouse, and Miall, 2011: 246). Beyond the space of political institutions reshaped by constitutionalism, such as parliaments and electoral systems, there are a number of institutional domains in which transformation is imperative if politics is to flourish. I include among these land reform and economic redistribution, policing and justice, health, housing, education, and the roles of civil society and religious institutions. Without institutional transformation, conflict is more likely to transmit to future generations, whose lives will remain unchanged by any tangible 'peace dividend.' For political reconciliation to be sustained, therefore, there must be visible, tangible progress in spaces of social transformation and reconstruction, without which efforts to cooperate across entrenched divisions may be undermined by the escalation of social discontent, and potentially even the collapse of a new political order (Villa-Vicencio, 2009: 5).

The research underpinning this framework reveals the extent to which these spaces of material and institutional transformation are also spaces of conflict within which a great deal is at stake. Conflicts over institutional transformation are imbued with political power imbalances characterised by the resistance of those who have benefited from previously repressive regimes to any change in the status quo. This is particularly the case with regard to the transformation of economic structures and institutions in order to build more equitable relations between former enemies. Economic transformation may involve the redistribution of wealth, land reform, or the payment of reparations. These reforms are, however, often resisted by those who have previously enjoyed great wealth - despite the fact that continuing material deprivation is a persistent source of conflict that will impede reconciliation unless there is political space available through which to contest these inequities. Without political capacity to pursue the transformation of economic institutions, even in the face of elite resistance, 
these conflicts risk becoming a zero-sum game that allow little space for reconciliatory engagement.

Both the South African and Australian examples, discussed above, demonstrate the longevity of contests over resources, dating from invasion and colonisation and continuing until the present day. Australia, for example, has witnessed decades of struggle for the recognition of the prior and distinct nature of Indigenous landholding. Aboriginal and Torres Strait Islander people have attempted to open political space through a range of strategies, including the 1963 bark petitions sent to the federal parliament by the Yolngu people of northeast Arnhem Land in protest over the mining of their land on the Gove peninsula. ${ }^{4}$ In the 1971 Gove land rights case (established in response to Yolngu claims) it was accepted that the eleven claimant clans did indeed have a system of land ownership, but it was determined that the communal nature of that ownership, which bore little resemblance to western property law, meant it could not be recognised in law. This view was maintained until the 1992 Mabo case, where the High Court of Australia determined that the communal ownership of land by indigenous people did constitute a unique form of title to land that had existed prior to colonisation. The 1993 Native Title Act, the legislative response to the Mabo decision, created collective rights to land in the Australian legal system.

However, this push for reconciliatory land reform in Australia also underscores the resistance to transformation in this domain. The mining and pastoral industries - the most significant stakeholders in issues of land use and ownership other than Aboriginal and Torres Strait Islander peoples-have been politically highly influential, waging a major public relations campaign against the native title reforms of the 1990s (Short, 2008: 128), to the disadvantage of Aboriginal people. Indeed, the 
mining industry opposed the proposed Native Title Act during 1993 negotiations, and the compromises made to ensure the passage of the legislation severely limited its transformative potential, particularly in the southern states where Aboriginal people had borne the full brunt of invasion and dispossession.

Ultimately, rather than keeping open the political space created by activism and transformative legal judgements such as Mabo, the space of agonistic engagement has been repeatedly closed down by elite resistance and compromise legislation, driving enduring conflicts over land justice in Australia out of the public domain. These conflicts are not, however, 'resolved', and are guaranteed to surface again at some future time to reclaim a place in Australian political reconciliation. In the meantime, however, the closing down of the nation's more agonistic engagement over questions of land justice have undermined reconciliation efforts, further weakening already fragile relations of trust between Aboriginal and Torres Strait Islander peoples and the Australian state. While limited in terms of any structural transformation, the Reconciliation Australia programme developing Reconciliation Action Plans (RAPs) (which support private and public organisations to identify actions they can take to improve the relationship between Indigenous people and other Australians), is a rare example of economic elites demonstrating preparedness to engage with questions of reconciliation and socioeconomic redistribution. It could be hoped that other deeply divided societies might also develop strategies in which economic elites may be drawn into a more productive engagement with questions of reconciliation and conflict transformation.

\section{Relational reconciliation}


The last level of analysis in the framework outlined in this article is the relational level, which concerns the transformation of relationships among people. This level is perhaps closest to more popular understanding of reconciliation, pointing to the ways in which reconciliation addresses both historical wounds and their contemporary, relational manifestations. Indeed, the very concept of reconciliation is based on the idea that a stable future order, of the kind initiated in political reconciliation, is only possible if the psychological sources of conflict are engaged alongside broader efforts at constitutional and institutional transformation. Scholars from a range of disciplines have stressed the importance of focusing on the underlying psychological and sociological needs that animate conflictual relations, including needs for recognition, acceptance, respect, security, and justice (Tropp, 2012: 4). It is in practices of relational engagement that attempt to address these needs that we can most clearly see the requirements for agonistic processes able to support difficult, ongoing conversations about the past: conversations about truth and justice, about forgiveness, about identity, and about learning to live together without violence.

One key aspect of relational engagement concerns a community's understanding of the past. Violent conflicts, of course, produce more than social division. Although many high profile commissions have established themselves with the goal of seeking a singular 'truth', war and violence in fact produce different histories; different understandings of the past that can become the most contested aspect of any reconciliation process. As Brenna Bhandar (2007: 95) argues, many versions of reconciliation maintain a demand for one version of historical truth to be agreed in order for society to agree to restitution and move on. The reality, she contends, is that history is 'a compilation of different threads of memory, threads that are intertwined but also in conflict', meaning that the idea of a single, shared truth about the past is 
'nothing more than a fiction.' An agonistic approach suggests that there will never be consensus on the past, there will always be multiple truths, multiple histories, that must somehow coexist, ideally in a democratic, non-violent political engagement.

An appreciation of this more contentious reality about the conflicting threads of history reveals much of what is at stake when reconciliation turns to consider the past. The particular ambition in post-conflict societies is to democratize history, replacing narratives controlled by elites with narratives that reflect the lives of poor, marginalized, and oppressed groups, revealing history as another 'territory of injustice' that might be addressed through an agonistic, dialogical engagement between truth and official discourses (Sanford, 2003: 181; Barkan, 2000: xxxiv). The case of Northern Ireland, where an inability to contend with this reality has stymied the political capacity to attend to questions of history and memory, illustrates this point. The desire to end the violence and create greater social stability in Northern Ireland led to avoidance of the contentious issue of historical responsibility in the deliberations that produced the 'fault neutral' framework of the Belfast Agreement (Aiken, 2010: 175). Thus, despite the fact that a formalised 'peace' has been in place since 1998, bolstered by the devolved power sharing arrangements in effect since 2007, Northern Ireland remains a deeply segregated society in which outbreaks of low-level violence between the two communities are not uncommon.

Chief among the obstacles to further reconciliation in Northern Ireland is continuing and profound disagreement about the past. While the necessity of peace is widely agreed and supported, there is no consensus about 'the morality (or otherwise) of the use of violence during the Troubles or to who the "real" victims and perpetrators of past violence are' (Aiken, 2010: 175). There has been a persistent level of anxiety that 
'genuine reconciliation' would require an unacceptable compromise involving the 'rehumanisation of old enemies' (Hamber and Kelly, 2005: 11). Indeed, more than any other issue, this anxiety about the past continues to undermine the belief that Northern Ireland has left the Troubles behind (Nolan, 2012: 11-12). The failure to communicate about the past, and the lack of a common understanding about the history and causes of past violence, reinforces the sense of isolation and difference between the two communities, underscoring the persistent threat of violence and impeding other reconciliation efforts (McCaughey, 2003: 181; Community Relations Council, 2011: 27).

Little (2012: 76) suggests that, despite the years that have passed since the Belfast Agreement, today many people prioritise the relative peace of the present over the risks of reconciliation, with its attendant requirement to face past conflicts and deal with the ways in which they continue to resonate in the present. Yet these questions remain very much a part of present-day politics. In 2009 the Consultative Group on the Past released the report Dealing with the Past in Northern Ireland (generally referred to as the Eames Bradley report after its authors) based on two years of consultations across Northern Ireland. The report made several significant recommendations including proposals to establish a Legacy Commission to integrate reconciliation, justice and information recovery processes, to conduct public acts of remembrance, and, most controversially, a recommendation for $£ 12,000$ recognition payments to relatives of those killed during the conflict. The report was widely criticised and eventually shelved. More recently still, in 2013, the Northern Irish political parties agreed to a new round of negotiations that they hoped would lead to agreement on parades, flags, and dealing with the past. The negotiations, known formally as the Panel of the Parties of the Northern Ireland Executive, or more 
colloquially as the Haass-O'Sullivan talks after the negotiation chairs, made some progress in some of these areas, particularly on dealing with the past, but ultimately were unable to reach an agreement by the agreed deadline of 31 December 2013, leaving the future of the negotiations uncertain.

This example is particularly illuminating in terms of the argument for agonistic engagement that has been advanced in this article. While ostensibly opening new political space in which to discuss the past in Northern Ireland, in fact the drive towards consensus saw the Haass-O'Sullivan talks prematurely close down political space through the imposition of an arbitrary deadline. In contrast, I would suggest that addressing the past in Northern Ireland in ways that might eventually transform relationships there will require a form of relational engagement that is intentionally agonistic, perhaps in the form of agonistic dialogue processes that I have discussed elsewhere (see Maddison, 2014). Schaap reminds us that political reconciliation does not require antagonists to agree about the significance or 'truth' of past events, only that they acknowledge that they are in fact talking about the same events. Through what Schaap describes as 'engaging in incessant discourse about the world that lies between former enemies' it is hoped that the capacity to share understanding about this world might become possible (Schaap, 2005: 84). Designed within an agonistic framework, the goal of such processes is to expand understanding of other perspectives, increasing the social and political capacity for difference to coexist and inform a non-violent democracy. While agreement about the past may be impossible in Northern Ireland, creating agonistic spaces in which both ordinary citizens and political elites can engage in incessant democratic discourse, through intentional and strategic processes of public dialogue, and without recourse to violence remains a political possibility. 


\section{Conclusion}

In the wake of violence, societies attempting to transform violent conflict must confront a plethora of demands, across multiple levels of society, some of which risk reopening old wounds or disrupting a fragile peace. The challenges involved in these processes are immense, but in most societies emerging from violent conflict there is also to be found considerable energy and enthusiasm being directed towards these efforts. In post-violent conflict societies around the globe it is possible to observe political actors of all kinds engaging in a politics of reconciliation across the multiple socio-political levels outlined here, with all the risks and complexities that this implies. Some of this effort attains a high public profile, with attendant media discussion and political debate that promote a wider public engagement. Much more is happening at the local and community level, in work led by small non-government organisations concerned to engage in relational transformation efforts with impacts that are less visible and far more difficult to measure. Yet all of these efforts, from the more to the less visible, contribute to transforming the constitutions, institutions and relations within deeply divided societies. Thus, to return to the question framing this article: Can we reconcile? My answer is yes, but only if we rethink the concept of reconciliation itself, and understand it as a complex, multi-level, process of constitutional, institutional and relational transformation, in which conflict will always be present, and has potential to be both creative and democratic. An understanding of these challenges may help defray the frustration experienced by actors on the ground, who infrequently experience political reconciliation as 'success.' 
The framework that this article has mapped out makes clear that the process of transforming conflict is indeed challenging. It is not just multi-level, it is likely also multi-generational, engaging the temporal and emotional dimensions that Adrian Little addresses in his article in this issue. It is rarely linear, and the levels themselves are porous and overlapping. Reconciliation may not be able to meet all of these demands, either in the short or the long term; there may be no end to human efforts to right past wrongs. These limitations should not, however, 'excuse inaction, naïve idealism, or undue delay' (Villa-Vicencio and Doxtader, 2004: ix). Crucially, these efforts at reconciliation will not, and should not, do away with conflict, but instead retain a focus on harnessing conflict's powerful, democratic potential. As Charles Villa-Vicencio (2009: 155) argues:

Never easy, reconciliation does not presuppose agreement on all solutions to all such issues. It does presuppose a willingness to address these concerns politically rather than in blood. This requires a willingness to think new thoughts and imagine new solutions.

The approach to reconciliation suggested here acknowledges that meaningful conflict transformation requires patience, persistence, creativity, risk, tolerance of conflict, and substantial government backing and investment over a long period of time. As a process, reconciliation will not 'end with a flourish', but it may be hoped that over time a political emphasis on reconciliation may give way to 'the day-to-day stuff of normal politics' (Daly and Sarkin, 2007: 254). Caution is needed however. Even a country like Australia, where it might be said that day-to-day politics now takes precedence over the politics of reconciliation, cannot be said to 'be reconciled'. There have been many moments in which Australians have sought to put the process of 
reconciliation in the past, most recently on the occasion of the 2008 Apology to the Stolen Generations. ${ }^{5}$ As Schaap reminds us however, political reconciliation is forever confronted by the risk of politics, as 'the will to forgive is confronted by the prospect of the unforgiveable', such that the new beginning we believe we have created does not come to pass, and old hurt and divisions come back to the fore (Schaap, 2005: 151). Thus a nation may find itself engaged in the politics of reconciliation once more, perhaps at a different level - in Australia the register has shifted from apology to constitutional reform - often avoiding the underlying transformations that would address historical disadvantage and dispossession. Yet rather than something to be avoided, this ever-conflictual reconciliation can be understood as the stuff of democratic politics. Developing a deeper understanding of the institutions and practices required to facilitate agonistic engagement across the socio-political levels mapped in this article, will be a priority in future research on political reconciliation.

\section{References}

African National Congress. 2012. The Second Transition? Building a National

Democratic Society and the Balance of Forces in 2012. Version 6.0 as amended by the Special NEC, 27 February ed. Johannesburg: ANC.

Aiken, Nevin T. 2010. "Learning to Live Together: Transitional Justice and Intergroup Reconciliation in Northern Ireland.” International Journal of Transitional Justice 4

(2): 166-188.

Arthur, Paige. 2011. "Introduction: Identities in Transition." In Identities in Transition: Challenges for Transitional Justice in Divided Societies, edited by Paige Arthur, 1-14. New York: Cambridge University Press. 
Barkan, Elazar. 2000. The Guilt of Nations: Restitution and Negotiating Historical Injustices. Baltimore: The Johns Hopkins University Press.

Bashir, Bashir and Will Kymlicka. 2008. "Introduction: Struggles for Inclusion and Reconciliation in Modern Democracies." In The Politics of Reconciliation in Multicultural Societies, edited by Bashir Bashir and Will Kymilicka, 1-24. Oxford, UK: Oxford University Press.

Behrendt, Larissa. 2003. Achieving Social Justice: Indigenous Rights and Australia's Future. Sydney: Federation Press.

Bhandar, Brenna. 2007. ""Spatializing History" and Opening Time: Resisting the Reproduction of the Proper Subject." In Law and the Politics of Reconciliation, edited by Scott Veitch, 93-110. Aldershot: Ashgate Publishing Ltd.

Brahm, Eric. 2003. “Conflict Stages.” In Beyond Intractability, edited by Guy Burgess and Heidi Burgess. Boulder: Conflict Research Consortium, University of Colorado.

Castan, Melissa. 2000. "Reconciliation, Law and the Constitution." In Reconciliation: Essays on Australian Reconciliation, edited by Michelle Grattan, 202-209.

Melbourne: Black Inc.

Christodoulidis, Emilios and Scott Veitch. 2007. "Introduction." In Law and the Politics of Reconciliation, edited by Scott Veitch, 1-8. Aldershot: Ashgate Publishing Ltd.

Community Relations Council. 2011. Towards a Shared Society? Response to the Consultation on the Programme for Cohesion, Sharing and Intergration. Belfast: Community Relations Council. 
Connolly, William E. 1991. Identity/Difference: Democratic Negotiations of Political Paradox. expanded ed. Minneapolis: University of Minnesota Press.

Coser, Lewis 1956.The Functions of Social Conflict. New York: The Free Press, Daly, Erin and Jeremy Sarkin. 2007. Reconciliation in Divided Societies: Finding

Common Ground. Philadelphia: University of Pennsylvania Press.

Fraser, Nancy. 1997. Justice Interruptus: Critical Reflections on the "postsocialist" Condition. New York: Routledge.

Guelke, Adrian. 2012. Politics in Deeply Divided Societies. Cambridge: Polity Press. Hamber, Brandon and Gráinne Kelly. 2005. A Place for Reconciliation? Conflict and Locality in Northern Ireland. Belfast: Democratic Dialogue.

Hirsch, Alexander Keller. 2012. "Introduction: The Agon of Reconciliation." In Theorizing Post-Conflict Reconciliation, edited by Alexander Keller Hirsch, 1-10. London: Routledge.

Langton, Marcia and Noel Loos. 2008. "Kara Ged: Homeland. the Dawn is at Hand." In The First Australians: An Illustrated History, edited by Rachel Perkins and Marcia Langton, 331-377. Melbourne: The Miegunyah Press.

Lederach, John Paul. 2005. The Moral Imagination: The Art and Soul of Building Peace. New York: Oxford University Press.

Lipset, Seymour M. 1960. Political man: The social bases of politics. New York:

Doubleday

Little, Adrian. 2014. Enduring Conflict: Challenging the Signature of Peace and Democracy. New York: Bloomsbury Publishing. 
Little, Adrian. 2012. "Rhetorics of Reconciliation: Shifting Conflict Paradigms in Northern Ireland." In Theorizing Post-Conflict Reconciliation, edited by Alexander Keller Hirsch, 65-78. London: Routledge.

McCaughey, Terence. 2003. "Northern Ireland: Burying the Hatchet, Not the Past." In Burying the Past: Making Peace and Doing Justice After Civil Conflict, edited by Nigel Biggar, 287-303. Washington D.C.: Georgetown University Press.

Maddison, Sarah. 2014. "When deliberation remains out of reach: The role of agonistic engagement in divided societies", in Ugarriza, J. and Caluwaerts, D. (eds), Democratic deliberation in deeply divided societies: From conflict to common ground, Palgrave, New York, pp. 189-205.

Maddison, Sarah. 2015. Conflict transformation and reconciliation: Multi-level challenges in deeply divided societies. London: Routledge.

Mouffe, Chantal. 2007. "Democracy as Agonistic Pluralism." In Rewriting

Democracy: Cultural Politics in Postmodernity, edited by Elizabeth Deeds Ermarth, 36-45. Aldershot: Ashgate.

Mouffe, Chantal. 2000. The Democratic Paradox. London: Verso.

Mouffe, Chantal. 2005. On the Political. London: Routledge.

Muldoon, Paul and Andrew Schaap. 2012. "Confounded by Recognition: The Apology, the High Court and the Aboriginal Embassy in Australia." In Theorizing Post-Conflict Reconciliation, edited by Alexander Keller Hirsch, 182-199. London: Routledge.

Nolan, Paul. 2012. Northern Ireland Peace Monitoring Report. Belfast: Community Relations Council. 
Ramphele, Mamphela. 2008. Laying Ghosts to Rest: Dilemmas of the Transformation in South Africa. Cape Town: Tafelberg.

Ramsbotham, Oliver. 2010. Transforming Violent Conflict: Radical Disagreement, Dialogue and Survival. London: Routledge.

Ramsbotham, Oliver, Tom Woodhouse, and Hugh Miall. 2011. Contemporary Conflict Resolution. Third ed. Cambridge: Polity Press.

Reilly, Charles A. 2009. Peace-Building and Development in Guatemala and Northern Ireland. New York: Palgrave Macmillan.

Renner, Judith. 2012. "A Discourse Theoretical Approach to Transitional Justice Ideals: Conceptualising 'Reconciliation' as an Empty Universal in Times of Political Transition." In Critical Perspectives in Transitional Justice, edited by Nicola Palmer, Phil Clark and Danielle Granville, 51-71. Cambridge: Intersentia Publishing. Sanford, Victoria. 2003. Buried Secrets: Truth and Human Rights in Guatemala. New York: Palgrave Macmillan.

Schaap, Andrew. 2006. "Agonism in Divided Societies." Philosophy \& Social Criticism 32 (2): 255-277.

Schaap, Andrew. 2005. Political Reconciliation. London: Routledge.

Schaap, Andrew. 2004. "Political Reconciliation through a Struggle for Recognition?" Social and Legal Studies 13 (4): 523-540.

Schaap, Andrew. 2007. "The Time of Reconciliation and the Space of Politics." In Law and the Politics of Reconciliation, edited by Scott Veitch, 9-31. Aldershot: Ashgate Publishing Ltd. 
Short, Damien. 2008. Reconciliation and Colonial Power: Indigenous Rights in Australia. Aldershot: Ashgate.

Simmel, Georg. 1903. "The sociology of conflict', American Journal of Sociology, 9: $490-525$.

Sparks, Allister. 2003. Beyond the Miracle: Inside the New South Africa. Chicago: University of Chicago Press.

Tropp, Linda R. 2012. "Understanding and Responding to Intergroup Conflict: Toward an Integrated Analysis." In The Oxford Handbook of Intergroup Conflict, edited by Linda R. Tropp, 3-10. New York: Oxford University Press.

Verdeja, Ernesto. 2009. Unchopping a Tree: Reconciliation in the Aftermath of Political Violence. Philadelphia: Temple University Press.

Villa-Vicencio, Charles. 2009. Walk with Us and Listen: Political Reconciliation in Africa. Washington D.C.: Georgetown University Press.

Villa-Vicencio, Charles and Erik Doxtader, eds. 2004. Pieces of the Puzzle: Keywords on Reconciliation and Transitional Justice, edited by Charles Villa-Vicencio andErik Doxtader. Cape Town: Institute for Justice \& Reconciliation.

Villa-Vicencio, Charles and Mills Soko. 2012. Conversations in Transition: Leading South African Voices. Cape Town: New Africa Books.

Wessels, Leon. 2010. "Good Faith is Not enough: We have to Dialogue." In In the Balance: South Africans Debate Reconciliation, edited by Fanie du Toit and Erik Doxtader, 8-16. Johannesburg: Jacana Media.

Wingenbach, Ed. 2011. Institutionalizing Agonistic Democracy: PostFoundationalism and Political Liberalism. Farnham: Ashgate. 
1 The positive framing of the political and sociological significance of conflict in stable democracies owes a debt to the seminal work on the subject by Georg Simmel (1903), Lewis Coser (1956) and (particularly in relation to democratic contribution of class conflict) Seymour Martin Lipset. Simmel and Coser in particular emphasized the potential benefits of social conflict in terms of innovation, social change and social integration.

2 This project, funded through an Australian Research Council, mid-career Future Fellowship, was a comparative study of reconciliation efforts in South Africa, Northern Ireland, Australia, and Guatemala.

3 Unlike theories of deliberative democracy, which have now been extensively applied and tested through models such as people's assemblies and citizen juries, agonism remains primarily in the realm of normative political theory. An emerging 'institutional turn' in agonistic theory (see for example Wingenbach 2011) shows early signs of addressing this lacuna, although much remains to be done.

4 In August 1963 two 'bark petitions' were presented to Australia's federal parliament. The typed text of the petitions, in both English and Gumatj languages, protested the excision of 300 square kilometres of the land of the Yolngu people of northeast Arnhem Land, to be leased to a bauxite mining company without their consent. The petitions were framed by paintings of sacred clan designs communicating ancestral narratives of creation and of the land and sea estates of the Yolngu, making them the 
first traditional documents to be recognised by the Commonwealth Parliament (Langton and Loos 2008: 349).

5 Coined by historian Peter Read in the 1980s, the term 'stolen generation' has, according to Robert Manne, taken on a similar significance for Indigenous Australians as the term 'the Holocaust' has for Jews (Manne 2001: 82). A key recommendation of the report Bringing Them Home: Report of the National Inquiry into the Separation of Aboriginal and Torres Strait Islander Children from Their Families was that all Australian governments should officially and publicly apologise to the 'Stolen Generations' for the harms done by past policies. This recommendation was rejected by the government of the day, but taken up by the newly elected Prime Minister, Kevin Rudd in 2008, who made good on his election promise that he would make a formal apology to the stolen generations. During the first sitting of the new parliament Rudd made a moving speech of apology in the House of Representatives that produced an outpouring of emotion around the country. 


\section{University Library}

\section{- M M N E R VA A gateway to Melbourne's research publications}

Minerva Access is the Institutional Repository of The University of Melbourne

Author/s:

Maddison, $S$

Title:

Can we reconcile? Understanding the multi-level challenges of conflict transformation

Date:

2017-03-01

Citation:

Maddison, S. (2017). Can we reconcile? Understanding the multi-level challenges of conflict transformation. INTERNATIONAL POLITICAL SCIENCE REVIEW, 38 (2), pp.155-168. https:// doi.org/10.1177/0192512115607953.

Persistent Link:

http://hdl.handle.net/11343/292088 